\title{
TRIPLE-WAVELENGTH LIDAR OBSERVATIONS OF THE LINEAR DEPOLARIZATION RATIO OF DRIED MARINE PARTICLES
}

\author{
Moritz Haarig 1,*, Albert Ansmann ${ }^{1}$, Holger Baars ${ }^{1}$, Ronny Engelmann ${ }^{1}$, Dietrich \\ Althausen ${ }^{1}$, Stephanie Bohlmann ${ }^{1, a}$, Josef Gasteiger ${ }^{2}$ and David Farrell ${ }^{3}$ \\ ${ }^{1}$ Leibniz Institute for Tropospheric Research (TROPOS), Germany, * haarig@ tropos.de \\ ${ }^{2}$ Faculty of Physics, University of Vienna, Austria \\ ${ }^{3}$ Caribbean Institute for Meteorology and Hydrology (CIMH), Barbados \\ ${ }^{\mathrm{a}}$ now at: Finnish Meteorological Institute, Kuopio, Finland
}

\begin{abstract}
For aerosol typing with lidar, sea salt particles are usually assumed to be spherical with a consequently low depolarization ratio. Evidence of dried marine particles at the top of the humid marine aerosol layer with a depolarization ratio up to 0.1 has been found at predominately maritime locations on Barbados and in the Southern Atlantic. The depolarization ratio for these probably cubic sea salt particles has been measured at three wavelengths $(355,532$ and $1064 \mathrm{~nm}$ ) simultaneously for the first time and compared to model simulations.
\end{abstract}

\section{INTRODUCTION}

The oceans are a large source of aerosol particles. The emitted sea salt is a widely spread aerosol type and serves as cloud condensation nuclei and ice-nucleating particle over the ocean [1]. The highly hygroscopic sea salt particles are usually of spherical shape in humid marine environments, resulting in a low particle linear depolarization ratio $(\mathrm{PLDR}=$ $0.03 \pm 0.01$ at $532 \mathrm{~nm}[2])$.

Under dry conditions, sea salt particles have a cubic-like shape [3]. With increasing relative humidity sea salt particles grow by wateruptake. Once a relative humidity of $70-74 \%$ is reached, sea salt particles are spherical [4].

In a laboratory study, Sakai [5] measured the PLDR of spherical sea salt particles (0.01) and crystalline sea salt particles $(0.08)$ at $532 \mathrm{~nm}$. In lidar field measurements, first evidence of an enhanced depolarization ratio was reported by Murayama [6] for dry marine particles based on measurements in Tokyo in 1999, but a clear separation from a potential dust influence was not possible.

Recent lidar measurements have been performed in the trade wind zone in the Eastern Caribbean and in the Southern Atlantic environments to study pure marine aerosols.

Pure marine conditions prevailed during the winter campaign (February-March 2014) of the Saharan Aerosol Long-Range Transport and Aerosol-Cloud-Interaction Experiment (SALTRACE) [7]. The campaign was conducted at the Caribbean Institute for Meteorology and Hydrology (CIMH), located at the west coast of Barbados $\left(13^{\circ} \mathrm{N}, 59^{\circ} \mathrm{W}\right)$. From 23 till 25 February 2014 enhanced depolarization was continuously observed at the top of the marine aerosol layer (MAL) because of dried marine particles. The free troposphere was absolutely dust-free so that no disturbance by non-marine aerosols was possible. For the first time, the particle linear depolarization ratio at three wavelengths (355, 532 and $1064 \mathrm{~nm}$ ) of non-spherical sea salt layers has been measured. A case study of the dry marine particle depolarization ratio at three wavelengths will be discussed in section 3 .

\section{LIDAR SYSTEM}

The multi-wavelength polarization Raman lidar BERTHA (Backscatter Extinction lidar-Ratio 
Temperature Humidity profiling Apparatus) of the Leibniz Institue for Tropospheric Research (TROPOS) is a container-based mobile lidar system. It enables the measurement of the depolarization ratio at three wavelengths simultaneously. Currently it operates as a $3+2+3$ lidar system ( 3 backscatter coefficients, 2 extinction coefficients and 3 depolarization ratios). A more detailed description has been given at the $27^{\text {th }}$ ILRC by Haarig [8] and in [9].

The signals are detected with a range resolution of $7.5 \mathrm{~m}$ and a time resolution of $10 \mathrm{~s}$. To ensure the good quality of the depolarization measurements, a $\Delta 90^{\circ}$ calibration [10] was performed regularly. Vaisalla RS92 radiosondes were launched and the temperature and pressure profiles were used to compute the molecular contribution to the measured lidar signals.

\section{MEASUREMENT EXAMPLE}

A very pronounced case of a thin layer of dried marine particles was observed over Barbados on 24 February 2014. A well mixed marine aerosol layer reached up to $2 \mathrm{~km}$ (Fig. 1). The feature of interest is the enhanced signal in the upper $200 \mathrm{~m}$ of the aerosol layer measured in the $1064 \mathrm{~nm}$ cross polarized channel. This feature is not visible in the color plot of the $1064 \mathrm{~nm}$ range-corrected total signal (upper panel in Fig. 1).

The radiosonde launched at 23:07 UTC shows a strong temperature inversion of $4 \mathrm{~K}$ at $2 \mathrm{~km}$ height (Fig. 2). In the MAL, RH was about $70 \%$ to $80 \%$. RH decreased to values of about $5 \%$ within about $200 \mathrm{~m}$ just above MAL top. Marine particles lost their water shell and their spherical shape at the top of the MBL and this caused enhanced depolarization. Figure 2 shows the relative humidity profile from the radiosonde and the $1064 \mathrm{~nm}$ volume depolarization. It can be seen that the volume depolarization partly reaches 0.06 till 0.08 at

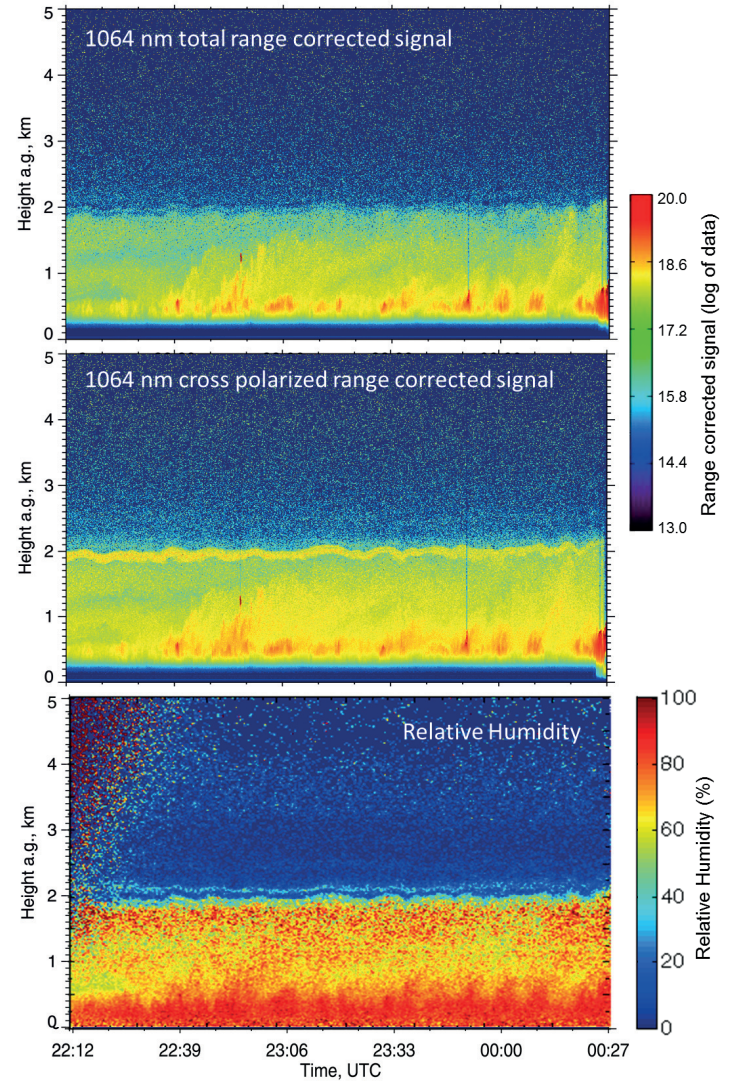

Figure 1: Range-corrected lidar signals for the $1064 \mathrm{~nm}$ total channel (upper panel) and $1064 \mathrm{~nm}$ cross polarized channel (central panel), measured at Barbados on 24 February 2014, 22:12 00:27 UTC. RH (lower panel) is derived from the water vapor channel $(407 \mathrm{~nm})$ and the temperature profile of the radiosonde (23:07 UTC).

the top of the MAL.

The particle backscatter coefficient and the PLDR for the three wavelengths $(355,532$ and $1064 \mathrm{~nm}$ ) of the BERTHA lidar system are shown in Fig. 3. In the 2 hour profiles, a maximum PLDR of $0.055(355 \mathrm{~nm}), 0.068$ $(532 \mathrm{~nm})$, and $0.038(1064 \mathrm{~nm})$ is reached in the thin layer of dried marine aerosol. Below in the humid MAL, the PLDR is below 0.02. The laboratory measurements by Sakai [5] for dried sea salt particles $(\mathrm{PLDR}=0.08$ at $532 \mathrm{~nm}$ ) are in good agreement with our finding. The 


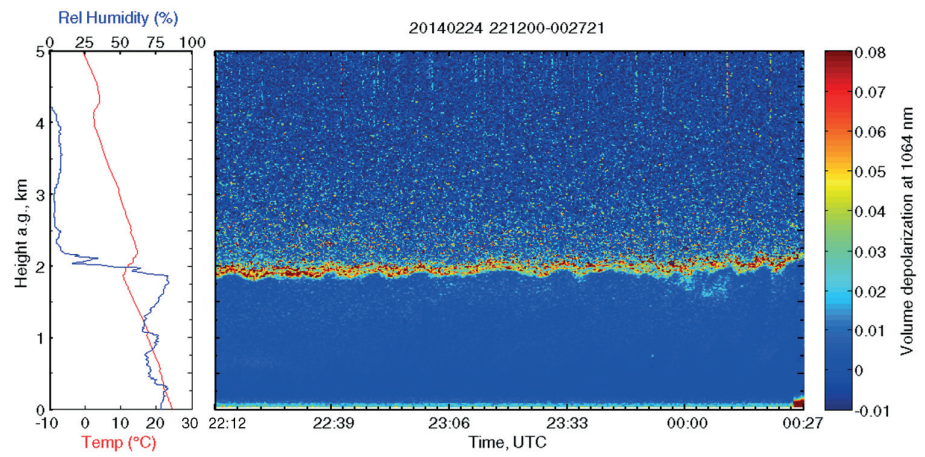

Figure 2: The temperature and relative humidity profile of the radiosonde launched at 24 February 2014 23:07 UTC (left) and the height-time display of the $1064 \mathrm{~nm}$ volume linear depolarization ratio (right).
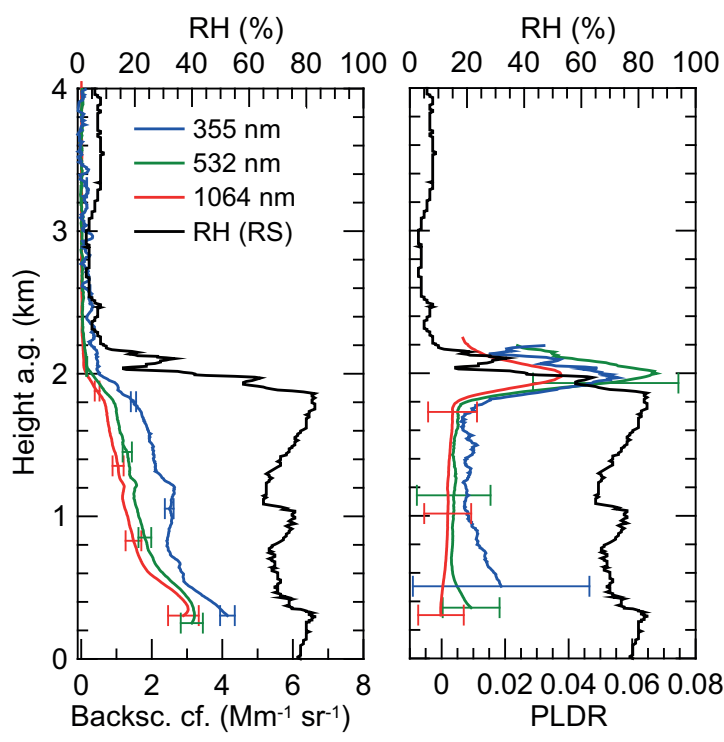

Figure 3: Vertical profiles of particle optical properties observed on 24 February 2014, 22:12 24:00 UTC. Shown are the particle backscatter coefficient (left) and the PLDR (right) at $355 \mathrm{~nm}$ (blue), $532 \mathrm{~nm}$ (green) and $1064 \mathrm{~nm}$ (red). The profile of $R H$ measured by the radiosonde is shown in both plots. Note that the drastic change in $\mathrm{RH}$ from $80 \%$ to less than $10 \%$ occurs within $200 \mathrm{~m}$.

profile of RH was added in Fig. 3 to show the coincidence of the decrease of RH with the increase of PLDR.

Model calculations predict a depolarization ratio of up to 0.15 at all three wavelengths for perfectly cubic sea salt particles for realistic size distributions of dried marine particles. However the dried sea salt particles cannot be of perfectly cubic shape, but have much smoother edges. Thus, the measured values for the enhanced depolarization ratio have to be smaller than the model predictions. Furthermore, mixing of spherical and cubic particles may occur at MAL top, what also decreases the depolarization ratio.

Similar results have been found on board of a research vessel over the Southern Atlantic. An extended Portable Lidar System (Polly ${ }^{\mathrm{XT}}$ ) [11] of TROPOS was deployed on board of the German research vessel Polarstern in the framework of OCEANET. The PLDR at 355 and $532 \mathrm{~nm}$ of dried sea salt particles was measured.

\section{CONCLUSIONS}

By means of a triple-wavelength polarization lidar the spectral dependence of the depolarization ratio of dried marine particles has been unambiguously measured for the first time. The observed enhanced depolarization ratio is in good agreement with laboratory studies. Discrepancies to model calculations indicate that 
the dried marine particles have a cubic-like shape with smoothed edges.

\section{References}

[1] DeMott, P. J., Hill, T. C. J., McCluskey, C. S., Prather, K. A., Collins, D. B., Sullivan, R. C., Ruppel, M. J., Mason, R. H., Irish, V. E., Lee, T., Hwang, C. Y., Rhee, T. S., Snider, J. R., McMeeking, G. R., Dhaniyala, S., Lewis, E. R., Wentzell, J. J. B., Abbatt, J., Lee, C., Sultana, C. M., Ault, A. P., Axson, J. L., Diaz Martinez, M., Venero, I., Santos-Figueroa, G., Stokes, M. D., Deane, G. B., Mayol-Bracero, O. L., Grassian, V. H., Bertram, T. H., Bertram, A. K., Moffett, B. F., Franc, G. D., 2016: Sea spray aerosol as a unique source of ice nucleating particles, Proceedings of the National Academy of Sciences, 113, 5797-5803

[2] Groß, S., Esselborn, M., Weinzierl, B., Wirth, M., Fix, A., Petzold, A., 2013: Aerosol classification by airborne high spectral resolution lidar observations, Atmospheric Chemistry and Physics, 13, 2487-2505

[3] Chamaillard, K., Jennings, S., Kleefeld, C., Ceburnis, D., Yoon, Y., 2003: Light backscattering and scattering by nonspherical seasalt aerosols, Journal of Quantitative Spectroscopy and Radiative Transfer, 79-80, 577 $-597$

[4] Tang, I., Tridico, A. and Fung, K., 1997: Thermodynamic and Optical Properties of sea salt aerosols, Journal of Geophysical Research 102, 23269-23275

[5] Sakai, T., Nagai, T., Zaizen, Y., Mano, Y., 2010: Backscattering linear depolarization ratio measurements of mineral, sea-salt, and ammonium sulfate particles simulated in a laboratory chamber, Appl. Opt. 49, 4441-4449

[6] Murayama, T., Okamoto, H., Kaneyasu, N., Kamataki, H. and Miura, K., 1999: Application of lidar depolarization measurement in the atmospheric boundary layer: Effects of dust and sea-salt particles, Journal of Geophysical Research 104, 31781-31792
[7] Weinzierl, B., Ansmann, A., Prospero, J. M., Althausen, D., Benker, N., Chouza, F., Dollner, M., Farrell, D., Fomba, W. K., Freudenthaler, V., Gasteiger, J., Groß, S., Haarig, M., Heinold, B., Kandler, K., Kristensen, T. B., Mayol-Bracero, O. L., Müller, T., Reitebuch, O., Sauer, D., Schäfler, A., Schepanski, K., Spanu, A., Tegen, I., Toledano, C., Walser, A., 2017: The Saharan Aerosol Long-range Transport and Aerosol-Cloud-Interaction Experiment (SALTRACE): overview and selected highlights, Bulletin of the American Meteorological Society, 98, 1427-1451

[8] Haarig, M., Althausen, D., Ansmann, A., Klepel, A., Baars, H., Engelmann, R., Groß, S., Freudenthaler, V., 2016: Measurement of the Linear Depolarization Ratio of Aged Dust at Three Wavelengths (355, 532 and $1064 \mathrm{~nm}$ ) Simultaneously over Barbados, EPJ Web of Conferences, 119, 18009

[9] Haarig, M., Ansmann, A., Althausen, D., Klepel, A., Groß, S., Freudenthaler, V., Toledano, C., Mamouri, R.-E., Farrell, D. A., Prescod, D. A., Marinou, E., Burton, S. P., Gasteiger, J., Engelmann, R., and Baars, H., 2017: Triple-wavelength depolarization-ratio profiling of Saharan dust over Barbados during SALTRACE in 2013 and 2014, Atmos. Chem. Phys., 17, 10767-10794

[10] Freudenthaler, V., Esselborn, M., Wiegner, M., Heese, B., Tesche, M., Ansmann, A., Müller, D., Althausen, D., Wirth, M., Fix, A., Ehret, G., Knippertz, P., Toledano, C., Gasteiger, J., Garhammer, M., Seefeldner, M., 2009: Depolarization ratio profiling at several wavelengths in pure Saharan dust during SAMUM 2006, Tellus B, 61, 165-179

[11] Engelmann, R., Kanitz, T., Baars, H., Heese, B., Althausen, D., Skupin, A., Wandinger, U., Komppula, M., Stachlewska, I. S., Amiridis, V., Marinou, E., Mattis, I., Linné, H., Ansmann, A., 2016: The automated multiwavelength Raman polarization and water-vapor lidar PollyXT: the neXT generation, Atmos. Meas. Tech., 9, 1767-1784 